\title{
AN ADMINISTRATIVE DIVISION OF THE NEW ZEALAND SUPREME COURT-A PROPOSAL FOR LAW REFORM
}

\author{
J. F. NORTHEY*
}

\begin{abstract}
Few lawyers in any country are satisfied with the existing arrangements for curial review of the decisions of administrative tribunals. The author examines the steps being taken in New Zealand to strike a better balance between administrative needs and the protection of the citizen. He proposes that an Administrative Division of the Supreme Court be established.
\end{abstract}

Few New Zealand lawyers are satisfied with the existing arrangements for curial review of decisions of administrative tribunals. There is also some measure of popular dissatisfaction. It is an area of law in which reform is both urgent and necessary. The New Zealand Minister of Justice, Hon. J. R. Hanan, recognized this when, in 1966, he announced the appointment of a Law Revision Commission and four Law Reform Committees, one of which was to be entitled the Public and Administrative Law Reform Committee. The Minister, in a lengthy policy statement issued in August, 1965, and entitled Law in a Changing Society, had indicated that it was his intention to replace the existing Law Revision Committee by a body better fitted not only to recommend the making of minor running repairs to the fabric of the law, but also to undertake the research needed to initiate broad reforms. In his view, increased use of Law Reform Committees, working within an overall plan approved by the Commission, would enable the Commission to bring far greater resources of personnel and experience to bear on the revision of the law.

\section{The Law Revision Commission and Law Reform Committees}

The Minister in 1966 announced the appointment of the Law Revision Commission with a membership of 19, with the Minister as chairman. The other members included five present or former Members of Parliament, seven practising lawyers, the Deans of the four Law Schools, the Secretary for Justice and the Counsel to the Law Drafting Office. One of the members of the Court of Appeal, Sir Alexander Turner, joined the Commission later. The Minister explained that the Commission was intended to function as a non-political body, in the sense that it was to approve the overall programme of law reform and to settle priorities within that programme and was only indirectly concerned with the political implications that some law reform measures might have. It was accepted that each of the Law Reform Committees would report to the Minister of Justice, who would make copies of their reports available to the members of the Commission; it was also recognized that the Minister was not obliged to wait for the Commission's approval of a report before initiating action on it.

When announcing the membership of the Commission, the Minister also named the members of the four Committees associated with the Commission. Four broad fields were defined and each allotted to a

- B.A., LL.M. (N.Z.), D.Jur. (Toronto), Dean of the Faculty of Law, the University of Auckland. 
Committee. The Public and Administrative Law Reform Committee was allotted four areas for consideration:

(1) appeals from administrative tribunals;

(2) judicial control of administrative acts;

(3) the constitution and procedure of tribunals; and

(4) Crown privilege.

The remaining fields were allotted to the Contracts and Commercial Law Reform Committee, whose specific tasks included mistake, illegality, misrepresentation, carriage of goods and chattels securities, the Torts and General Law Reform Committee charged with such questions as hearsay evidence, occupier's liability, family law and products liability, and the Property Law and Equity Committee which had responsibility for such questions as the law relating to executors and administrators, trustee investments and landlord and tenant.

Each of these four Committees has a membership of about eight persons, some of whom are also members of the Commission. Overlapping membership enables the Commission to be informed directly of the detailed work which preceded the completion of a report. It is recognized that the Commission should not attempt to traverse the ground already covered in great detail by the Committees, but general questions can be, and have been, raised in relation to reports when they are presented to the Commission. The Minister necessarily has a discretion whether he will invite the Commission to endorse a Committee's report before releasing it and inviting comments from interested Ministers, departments and others.

\section{The Public and Administrative Law Reform Committee}

The Public and Administrative Law Reform Committee has a membership of nine who sit under the chairmanship of the Secretary for Justice, who is a qualified lawyer. The other members are four practising lawyers, two law teachers with special interest and experience in Administrative Law and with some knowledge of Government, the Counsel to the Law Drafting Office and a former Secretary to the Treasury. The Committee began work early in 1966. Members had before them three reports which assisted them in their task. The first was a report issued by the Department of Justice, with the approval of the Minister of Justice, entitled The Citizen and Power: Administrative Tribunals. ${ }^{1}$ This report assembles most conveniently information concerning the 60 or so more important administrative tribunals functioning in New Zealand. It gives information on their membership, their relations with the interested departments, the procedure before, during and after hearing, and the scope of appeal rights or judicial review. A number of recommendations were made in the report concerning tenure of members, qualifications for appointment, manner of appointment and the procedures to be followed, including the need for publishing reasoned decisions.

An earlier report, entitled Administrative Justice in New Zealand," was written by one of the members of the Committee, Mr. Gordon Orr, Senior Crown Counsel in the office of the Solicitor-General. Mr. 
Orr wrote the report while he was a Harkness Fellow at Harvard University. He advocated the creation of an Administrative Court, modelled on the United Kingdom Restrictive Trade Practices Court, but with a general appellate jurisdiction over administrative tribunals. The Administrative Court would consist of a number of Divisions each of which would specialize in a given area. The Divisions he recommended included a Licensing Division, to which appeals in respect of licenses would be taken, a Town Planning and Local Government Division, a Land Valuation and Settlement Division which would replace the present Land Valuation Court, an Industrial Division with jurisdiction over workers' compensation, a Tax Division and a Trade Practices Division. Mr. Orr saw the Administrative Court as a Court of Record comprising Judges and associate members who would be laymen with experience in the field assigned to each of the various Divisions.

$\mathrm{Mr}$. Orr also favoured the enactment of an administrative code comparable to the Massachusetts Administrative Procedure Act 1954. His report, although published by the Government Printer with a foreword by the Minister of Justice, did not gain significant official or political support. It must be noted, however, that the reports made by the Department of Justice and $\mathrm{Mr}$. Orr have influenced the contents of recent legislation. An illustration is the Animal Remedies Act 1967, which is designed to control the manufacture, importation, sale and use of animal remedies. The objective is to be achieved by an Animal Remedies Board from whose decisions an appeal can be taken to an Appeal Tribunal. The Act expressly provides for a hearing at which the parties are entitled to legal representation and requires the observance of the principles of natural justice; ${ }^{3}$ the tribunal has power to award costs and to subpoena witnesses and must give a reasoned decision. The "supervisory jurisdiction of the Supreme Court" is also expressly preserved. These provisions are consistent with the recommendations of the Department of Justice and with the objectives to be secured by the enactment of a code of procedure binding on administrative tribunals.

The third report available to the Law Reform Committee was prepared by a special committee of the New Zealand Law Society. That Committee had accepted that administrative tribunals were necessary, but expressed the view that important changes should be made in respect of appeals from their determinations. Because the Law Reform Committee circulated a copy of that report to all interested Departments for their comments, the principal recommendations made on behalf of the Society should be summarized. It was recommended:

(1) that there be an appeal to the Supreme Court on questions of law;

(2) that all statutory tribunals be required to give reasoned decisions;

(3) that provisions ousting or limiting the supervisory jurisdiction of the Supreme Court be repealed;

(4) that there be an appeal on fact or discretion to the Supreme Court "on issues of importance";"

3 Thereby avolding the need to establish by other means that a duty to act judicially was cast upon the tribunal. This obligation must be established, in terms of Nakkuda Ali v. Jayaratne, [1951] A.C. 66, and subsequent decisions of the New Zealand Court of Appeal, in order to secure certiorari and prohibition.

4 This phrase was not defined, but presumably an appeal would lie at least in respect of decisions on such issues as the value of land, restrictions on trade practices and the determination of land uses under planning legislation. 
(5) that in those cases where an appeal to the Supreme Court on fact or discretion was thought to be undesirable, a specially constituted Court where the Judge would be assisted by persons with expert knowledge be given jurisdiction to hear appeals; and

(6) that a Committee be established to determine what appeal rights were appropriate in the case of each tribunal.

\section{The Procedure of the Law Reform Committee}

The Committee decided that each department of government should be asked to list the administrative tribunals with which it was concerned and to indicate to what extent the recommendations the Law Society's Committee would be appropriate for those tribunals. Although the replies ranged from a complete rejection of all of the recommendations to a guarded acceptance of most of them, there was little objection to the first recommendation concerning appeals on questions of law. It was pointed out that, although many statutes made provision for an administrative tribunal to state a case on a point of law to the Supreme Court, there had been only limited use of this power. There was also general support for the giving of reasons, but it was asserted that in some cases it would not be profitable. If, for example, the tribunal was asked to rule on the suitability of a person for promotion or appointment, any statement of reasons would necessarily be brief and of no real assistance to the person aggrieved. The recommendations concerning appeal rights in respect of decisions involving fact or discretion were almost unanimously rejected. The main grounds for this point of view were the unsuitability of the issue for decision by a Court, ${ }^{5}$ the delay and expense involved in further appeal rights, the satisfaction expressed with the existing arrangements by those primarily affected, the need for appropriate experience or knowledge, of the particular field which a Judge would be unlikely to possess, the policy elements involved and the undesirability of taking an appeal to a single Judge from a decision of a tribunal consisting of more than one member. The Committee, therefore, began its work with the knowledge that any change, particularly one which gave an appeal to the Courts on issues of fact or discretion, would meet substantial departmental resistance. At the very least, departmental inertia would need to be overcome.

\section{The First Report}

The first report of the Committee was published early in 1968. It covered the tribunals responsible for the valuation of land, town and country planning, transport licensing and charges, trade practices and prices. In each case, before reaching a conclusion, the Committee sought and considered the views of the interested departments, some of the members of the tribunals, and selected practitioners who had extensive experience in the work of each tribunal. At this point it might be appropriate to state the general conclusions reached by the Committee and then to discuss the recommendations made in relation to each tribunal.

\section{General Conclusions}

It was recognized that the increasing range of governmental activity in all modern states has presented them with the problem of finding a

s An obvious example is the price of goods. 
balance between administrative needs and the protection of the citizen. Each state is concerned to adopt the most effective means of decision making while providing the citizen with adequate protection against administrative excesses. The Ombudsman, whose office was introduced in New Zealand in 1962, has already achieved significant results not only in securing the redress of legitimate grievances but also in improving the standard of central administration. The United Kingdom, by the enactment of the Tribunals and Inquiries Act 1958 and the appointment of a Parliamentary Commissioner for Administration, has chosen slightly different methods of striking a "balance between the public interest which [administration] promotes and the private interest which it disturbs." The Law Reform Committee early recognized that "disputes accompanying the modern surge of governmental activity are often of great importance to the persons immediately concerned and to the general public." Though some of those disputes might have been resolved by the ordinary courts, it was accepted that, for a variety of reasons, they had been assigned to administrative tribunals which were "a valuable, and indeed an essential, part of the constitutional machinery ...",

But the reasons advanced for administrative tribunals were, in the opinion of the Committee, "either unconvincing or capable of being met [at the appellate level] by the changes we recommend." Already at the appellate level, it was noted that use had regularly been made of persons with legal qualifications similar to those laid down for appointment to the Supreme Court. The reluctance of the judiciary, in part explained by their narrow professional training, "to use [their] resourcefulness in applying a new piece of social legislation." ${ }^{10}$ was seen to be no longer prevalent. Moreover, some steps are being taken in New Zealand and elsewhere to remedy the failure of their legal training "to impart to [lawyers] any real understanding of the policy considerations implicit in the administrative process and of the social questions which are attempted to be solved by many legislative schemes." 11 But it remains true that some members of the bench and the legal profession are better able than others to appreciate the breadth of the issues involved and possess the necessary insights to achieve a just result. Hence, an Administrative Division to which Judges with this competence and turn of mind would be appointed is recommended.

The chief criticism from the legal profession and some of their clients is that, even if decisions are made by those styled Judges ${ }^{12}$ or by other persons with legal qualifications, they believe they have "received less than justice." 13 Moreover, there is a growing conviction which has been expressed by the present Chief Justice in this way:

It is a question whether the really important decisions affecting the citizen are being made by the men best qualified by training and experience to make them;

6 Report of the Committee on Administrative Tribunals and Enquiries, Cmnd. 218, at para. 21 (1957)

7 First Report of the Public and Administrative Law Reform Committee, 1968, para. 5.

8 Id., at para. 8.

9 Id., at para. 9 .

10 Rt. Hon. Sir Richard Wild, C.J., Social Progress and the Legal Process (1965), 27 N.Z.L.J., Pub. Adm. 1.

11 Hon. R. Else Mitchell, J., The Place of the Administrative Tribunal in 1965, Proceedings of the Third Commonwealth and Empire Law Conference 74 (1966).

12 The persons presiding over the Arbitration Court, the Land Valuation Court and the Compensation Court carry this title.

13 First Report of the Public and Administrative Law Reform Committee, 1968, para. 32 (ii). The phrase was taken from the Report of the Law Society's Committee. 
whether the community is losing the benefit of the influence of the courts in moulding the law in action.14

Sir Richard's belief was that "in the range and material value of their decisions the courts are losing their proper place. In the eyes of the ordinary man they are fading in importance." 15 The Chief Justice could, therefore, be taken to welcome any move which would give the Courts a share in the important tasks now performed by administrative tribunals.

But any change must take into account the consideration that lawyers and the Courts are not necessarily the best persons to take a decision involving a substantial policy element or concerning what is "not a justiciable issue." ${ }_{16}$ Two separate points arise. First, members of the judiciary may not be the best qualified persons to take these decisions; secondly, the involvement of the judiciary in political issues might affect their detachment or diminish their deservedly high standing in the eyes of the public. There is, it is suggested, a very real distinction, in terms of the problem to be resolved and the public's reaction to the decision, between a tax appeal involving legal issues primarily or exclusively and an appeal concerning the price of goods or services which is essentially an economic or political decision.

The majority ${ }^{17}$ of the Law Reform Committee was satisfied that an Administrative Division of the Supreme Court could assume much of the appellate work performed by the existing administrative appeal authorities. Numerous improvements would result. The anomolous status of the present authorities, being something less than that of a Judge, would be ended. Difficulties in recruiting qualified persons for these posts would be resolved. The work would be concentrated in fewer hands. There would be readier acceptance of the decisions taken. The determination of questions of law would rest with a better qualified body. But most important of all the technicalities and difficulties now facing a litigant seeking review would be overcome. Though there might remain a few cases where review might still be sought rather than an appeal taken, the majority of those dissatisfied with a determination of an administrative tribunal could be expected to exercise their right to appeal to the Administrative Division. That Division would not, of course, be subject, as inferior tribunals are at present, to the supervisory jurisdiction of the Supreme Court; the Administrative Division would be a part of the Supreme Court. Moreover, the existing supervisory jurisdiction of the Supreme Court would also be exercised by the Administrative Division. Because of the wider experience that members of that Division would possess they could be expected to achieve a greater measure of consistency in this area of law. It would also be reasonable to expect, if not a revolutionary, at least a different, approach to old problems.

\section{The Administrative Division}

The Committee has recommended that an Administrative Division of the Supreme Court be established and that three or four judges should be appointed to it. These judges would be available for other

14 Rt. Hon. Sir Richard Wild, C.J., The Place of the Administrative Tribunal in 1965, Proceedings of the Third Commonwealth and Empire Law Conference 80 (1966).

15 Id., at 79.

10 Ibid. 17 . Orr presented a dissenting report in which he advocated the establishment of an Administrative Court. 
Supreme Court work when required but their primary responsibility would be to exercise the supervisory and appellate powers of the Supreme Court in the field of Administrative Law. Persons selected for appointment to the Administrative Division would be those who had demonstrated their understanding of the changing role of the Courts and who could, therefore, be expected to have a full appreciation of the need to give effect to the economic and social policies the legislation in question was designed to achieve. It was recognized that lay members might be associated with the Judges where this was found to be desirable. The proceedings of the Division should not be more expensive or more formal than those of the present appellate tribunals. ${ }^{18}$ It was accepted that the Judges of the Administrative Division would travel to sittings of the Court outside Wellington and that in cases of special importance a Full Court could be assembled to take the appeal.

\section{Point of Law}

As will be seen when the recommendations in respect of particular tribunals are discussed, a distinction is drawn between questions of law and questions of fact or discretion. The Committee spent a great deal of time considering the meaning of "point of law" and whether a definition should be attempted. There are advantages to be gained from, and disadvantages attendant upon, defining "point of law." Because definition is seen to be difficult, it is probable that this question will be left to the Courts to resolve. This can be done with some confidence because it is unlikely that the term will be so narrowly interpreted that gross abuses of discretionary power will be left unchecked. The phrase is sufficiently flexible: thus a question of law can embrace excess or want of jurisdiction; error of law on the face of the record; misconstruction of a statute, regulation or document; non-compliance with the relevant legislative provisions; some errors concerning the admission or rejection of evidence; determinations based on irrelevant considerations or so unreasonable as to amount to a failure to exercise the discretion; some instances of refusal to exercise the jurisdiction and the breach of the principles of natural justice.

\section{Land Valuation Committees and Court}

The Law Reform Committee has recommended that the Land Valuation Committees should remain, but that the Land Valuation Court should be abolished and its functions taken over by the Administrative Division. Lay members could continue to sit with the Court when desirable. From the Administrative Division there would be an appeal with leave to the Court of Appeal on fact, law and merits. Certain criteria on which the discretion to grant leave to appeal would be exercised were included in the Committee's report. ${ }^{10}$

\section{Town and Country Planning}

The tribunal of first instance, the Planning Committee of the local body concerned, would remain, but improvements in procedures have been recommended. ${ }^{20}$ The existing Appeal Board would be retained,

18 It is recognized that these recommendations might be difficult to put into practice, e.g. would the members of the Administrative Division sit without wigs and robes?

10 Para. 48. 
it being recognized that it is only at this level that a true "hearing" occurs. From the Appeal Board an appeal may be taken with leave to the Administrative Division which would have jurisdiction over law, fact and merits. A further appeal to the Court of Appeal is recommended but only on questions of law.21

\section{Transport Licensing and Charges}

The District Licensing Authorities, which it was concluded had carried out their functions to the satisfaction of those affected, would continue to function at first instance. The existing Appeal Authority would be absorbed by the Administrative Division which would have jurisdiction over law, fact and discretion. No further appeal rights are recommended for the reasons stated by the Committee. ${ }^{22}$

Most transport charges are fixed administratively by the Commissioner of Transport. The Committee has recommended that no change be made in this respect and the powers of the Charges Appeal Authority should continue at least in the meantime. At a later date some amalgamation of bodies with similar functions might be recommended. An essential difference was seen between the issues raised on the one hand in the fields of land valuation, town and country planning and transport licensing and, on the other, those affecting transport charges. Decisions affecting the latter were not seen as an appropriate function of the Administrative Division. Some of the reasons for this distinction have already been discussed.

\section{Trade Practices}

The Law Reform Committee was advised that the work of the Trade Practices and Prices Commission had fallen off since the 1965 amendment to the Trade Practices Act, which enabled the Examiner of Trade Practices to reach a settlement after consultation with those affected. No change was therefore recommended at that level, but it was recommended that the Appeal Authority be absorbed into the Administrative Division which, again, would have jurisdiction over law, fact and discretion. ${ }^{23}$ An appeal to the Court of Appeal on a point of law only is recommended.

\section{Price Tribunal}

In this area the need for very close liaison with Government is apparent. It is recommended that a Controller of Prices within the Department of Industries and Commerce be given the powers now exercisable by the Price Tribunal and that the Controller act administratively. The effect of price orders was seen to be legislative and to differ from normal adjudication. From the decision of the Controller an appeal would lie to a Price Appeal Authority with jurisdiction over law, fact and discretion. ${ }^{24}$ The Appeal Authority, which would have a legally qualified chairman, would act judicially and normally be expected to give reasons for its decisions. There would not, however, be any further appeal right. The Price Tribunal and the Charges Appeal Authority,

\footnotetext{
21 Para. 58.

22 Para. 63.

23 Para. 77

24 Para. 84.
} 
already discussed, perform, in the view of the Committee, a different function from that to be exercised by the Administrative Division.

\section{Summary}

The Committee has recommended that appeals in respect of "justiciable" issues be taken to the Administrative Division, whose decision, apart from limited rights of appeal on questions of law, will be final. It has recognized that the Division should not be given responsibilities in fixing the price of goods and services. It has admitted the possibility that the work of the Arbitration Court, the Prices Appeal Authority and the Charges Appeal Authority might be merged in a single tribunal.

The Committee is continuing its work, but it expects that the pattern established so far might be found to suit the many other tribunals yet to be examined. Whether it would be wise to act on the first report, and thereby test the assumptions on which it is based, before the final report is made is a decision for the Government. Its intentions have not yet been disclosed. The Minister of Justice said, when releasing the report to the press, that he is anxious to have the fullest discussion of the proposals before legislation is drafted. The New Zealand Law Society has already declared its support for the proposals. The views of the other Ministers affected by the report have probably not been formulated, but it is almost certain that there will be some departmental opposition to the changes suggested. The attitude of the judiciary is seen to be crucial. If they take the position that they should become involved in what has formerly been the responsibility of administrative tribunals, the report has a substantial chance of being accepted by the Government. If the Judiciary share the very clearly expressed views of the Chief Justice, we may soon see not only a more coherent system of appeal rights, but also an incomparably simpler means of securing an authoritative pronouncement on the law as well as on the exercise of administrative discretion. It is not expected that any greater number of appeals will be taken or that a higher proportion will succeed; the onus of proving that the decision of the inferior tribunal was wrong will remain with the appellant. But the complainant will have a surer path to the Courts than the variety of routes he is now obliged to tread. If predictability of the outcome of legal proceedings is accepted as one of the important characteristics of the law, here too will there be a substantial improvement.*

- The Attorney-General has introduced the Judicature Amendment Bill which creates an Administrative Division of the Supreme Court, as recommended by the Public and Administrative Law Reform Committee, but some of its provisions differ from those recommended by the Committee. It is expected that the new Division will function from 1969. 